\title{
PRIVATE CRIMINAL REACH OF SECURITIES REGULATION*
}

THE RECENT case of Llanos v. United States ${ }^{1}$ invites reflection on the long reach of the federal criminal law into transactions involving promissory notes. The defendants had devised a scheme whereby they gave their own promissory notes to obtain money for their own use by making various false representations about their business connections and about the use to which the money was to be put. It was held that these acts amounted to the "sale" of a "security," and the defendants were convicted, inter alia, of fraud under the Securities Act of $1933 .^{2}$

There is, of course, nothing novel in the determination that a promissory note is a "security"3 for the purpose of the Securities Act and the state Blue Sky Laws, or that the issuing of such a note is a "sale." The Llanos case is, however, a strong reminder of the extent to which the criminal sanctions of the Securities Act may be applicable to even purely private transactions.

While private transactions are exempt from some provisions of the Securities Act, ${ }^{5}$ they are not exempt from those defining and penalizing

* Llanos v. United States, 206 F.2d 852 (gth Cir. 1953), cert. denied, 74. Sup. Ct. 3 30 (1954).

I 206 F.2d 852 (9th Cir. 1953), cert. denied, 74 Sup. Ct. 310 (1954).

248 STAT. 74 (1933), as amended, 48 STAT. 905 et seq. (1934), I5 U.S.C. $\$ 77 a$ et seq. (1946). Other counts on which conviction was based were violations of 62 STAT. 763 (1948), as amended, 63 STAT. 94 (1949), I8 U.S.C. § 1341 (Supp. 1952) (mail fraud) and 62 STAT. 70I (1948), I8 U.S.C. $\$ 37$ I (Supp. 1952) (conspiracy). For general discussion of the Securities Act see James, The Securities Act of 1933,32 MICH. L. REV. 624 (1934).

${ }^{3}$ "The term 'security' means any note ... evidence of indebtedness . . . or, in general, any interest or instrument commonly known as a 'security." Securities ACr, 48 STAT. 74 (1933), I5 U.S.C. $\$ 77 \mathrm{~b}(\mathrm{I})$ (1946). People v. Leach, Io6 Cal. App. 442, 290 Pac. I3I (I930); Niemeyer v. Dougan, 3 I Ga. App. 99, I Ig S.E. 544 (1923) (promissory note executed before passage of the Georgia Security Law, held not affected by the subsequent law). Cf. Securities \& Exchange Commission v. Sunbeam Gold Mines Co., 95 F.2d 699 (9th Cir. 1938) ("shareholder's receipt"); Cecil B. De Mille Productions v. Woolery, 61 F.2d 45 (9th Cir. I932) (corporntion's assignment of oil royalty interests as security for note evidencing debt, though not issued to the public). See Note, 87 A.L.R. 42 (1933). For a discussion of the Securities Act as compared with state legislation see Note, 28 CAL. L. REV. 410 (1940).

" "The term sale... shall include every disposition of . . . a security . . . for value. ..." Securities Act, supra note 3 at $\$ 77 \mathrm{~b}(3)$. Bogy v. United States, 96 F.2d 734 (6th Cir. I938), cert. denied, 305 U.S. 608 (1938).

'Securities Acr, 48 Stat. 74, 77 (1933), as amended, 48 Stat. 906, is U.S.C. 
fraud. ${ }^{6}$ True, most criminal prosecutions under these provisions have involved dealings with the public, ${ }^{7}$ but that feature is not an essential element of the statutory crime. Rather, there must only be a "sale"s of a "security" in connection with which there is fraud" and the use of interstate channels of communication. ${ }^{11}$ Further, under the Securities and Exchange Act of $1934^{12}$ and Rule X-IoB-5 $5^{13}$ based thereon, ${ }^{14}$ a purchaser as well as a seller ${ }^{15}$ may be criminally liable for fraud ${ }^{10}$

$\$ \S 77 \mathrm{~d}, 77 \mathrm{e}$ (1946). Comment, 36 Mich. L. REV. 604 (1938). For a more general discussion see Throop and Lane, Some Problems of Exemption Under the Securities Act of 2933,4 LaW \& CONTEMP. PROB. 89 (1937).

${ }^{\circ}$ Securities ACT, 48 Stat. 84-85 (1933), I5 U.S.C. \& 77q (1946) (definition of fraud), 48 STAT. 87 (1933), I5 U.S.C. $\$ 77 \times$ (1946) (penalties). For a discussion of fraud provisions see Notes, $x 8$ B.U.L. $6 \times 3$ (1938); 26 CoRNELl L. Q. 343 (x941).

${ }^{7}$ E.g., Securities \& Exchange Commission v. Ralston Purina Co., 346 U.S. I 19 (1953); Securities \& Exchange Commission v. Sunbeam Gold Mines Co., 95 F.2d 699 (gth Cir. 1938).

${ }^{8}$ See note 4 supra.

${ }^{\circ}$ See note 3 supra.

${ }^{10}$ It should be noted that the proscribed "fraud" is not the classical common law fraud which is associated with deceit, but, rather, the malpractices specifically enumerated in the Securities Act: "It shall be unlawful for any person in the sale of any security by the use of any means or instruments of transportation or communication in interstate commerce or by the use of the mails, directly or indirectly ... ( $x$ ) to employ any device, scheme, or artifice to defraud, or (2) to obtain money or property by means of any untrue statement of any material fact or any omission to state a material fact necessary in order to make the statements made, in the light of the circumstances under which they were made, not misleading, or (3) to engage in any transaction, practice, or course of business which operates or would operate as a fraud or deceit upon the purchaser." SECURITIES ACT, 48 STAT. 84 (I933), 15 U.S.C. $\S 779$ ( 1946$)$. For a discussion of civil liability, in a close corporation, involving the foregoing section consult Latty, The Aggrieved Buyer or Seller or Holder of Shares in A Close Corporation Under the S.E.C. Statutes, is LAW \& ConTEMP. Prop. 505 (1953).

${ }^{11}$ It is also to be noted that even an incidental use of federal channels such as the mails, Schillmer v. H. Vaughan Clarke \& Co., 134 F.2d 875 (2d Cir. 1943) or interstate trains, Moore v. Gorman, 75 F. Supp. 453 (S.D.N.Y. 1948), is enough to bring a case within this federal legislation. For a general discussion of these and related problems see Loss, SECURITIES REGULATION I001-1003, 876-882 (I951).

${ }^{12} 48$ STAT. 88 I (1934), as amended, 15 U.S.C. § 78 a, et seq. (x 946$)$.

${ }^{13}$ Rule X-roB-5, i7 CODE FED. REG. \& $240.10 b-5$ (x949). Comment, 32 TEX. L. REv. 197,203 (1953).

14 Securities Exchange ACT, 48 Stat. $89 \mathrm{I}$ (1934), I5 U.S.C. $§ 78 \mathrm{j}$ (1946).

${ }^{15}$ Recall that the Security Act, supra note ro, extends criminal liability only to the seller.

${ }^{10}$ "It shall be unlawful for any person, directly or indirectly, by the use of any means or instrumentality of interstate commerce, or of any facility of any national security exchange, (a) to employ any device, scheme, or artifice to defraud, (b) to make any untrue statement of material fact or to omit to state a material fact necessary in order to make the statements made, in the light of the circumstances under 
in connection with a security transaction. Again, the sanction is not limited to public offerings, but may extend to a purely private deal between individuals. ${ }^{17}$

A few illustrations suffice to point out the "private" reach of the criminal sanctions under this legislation, which is commonly thought of as dealing only with regulation of publicly held securities.

Example I: A, living in state $X$, telephones $B$ in state $Y$, telling $B$ that he would like to buy B's Blackacre and that he will pay part in cash and give his note for the balance. A falsely represents that he is solvent. B conveys Blackacre and receives A's note. Under Section I7 (a) of the Securities Act, A is subject to criminal prosecution for this private transaction, because all the requisite elements are present.

Example II: C, a jeweler, by letter to D, fraudulently represents that he has a ring for sale which is a genuine diamond. D, living outside of town, catches an interstate bus into town, and D, falsely representing his solvency, purchases the ring from $\mathrm{C}$ by giving a negotiable note. It is possible under the Exchange Act and Rule $\mathrm{X}$-roB-5 that both $\mathrm{C}$ and $\mathrm{D}$ would be liable to criminal prosecution in this private transaction because both have supplied all the requisite elements, respectively, of the statutory crime.

Thus, it should be apparent that, although the purpose of the Sesurities Act and of the Securities and Exchange Act was ostensibly the protection of the "public,"18 their language is so broad that many transactions, not ordinarily thought of as "security transactions," may unexpectedly come within their purview.

\section{Forrest E. Camprell}

which they were made, not misleading, or (c) to engage in any act, practice, or course of business which operates or would operate as a fraud or deceit upon any person, in connection with the purchase or sale of any security." Rule X-roB-5, supra note 13. It should be observed that the definition contained in this rule is almost identical with that contained in the Security Act, 48 STAT, 84 (1933), 15 U.S.C. \& 77q (1946).

${ }^{17}$ Kardon v. National Gypsum Co., 69 F. Supp. 512 (E.D. Pa. 1946); Northern Trust Co. v. Essaness Theatre Corp., 193 F. Supp. 954 (N.D. Ill. 1952) (fraudulent purchase of stock by insiders for resale).

${ }^{18}$ Securities \& Exchange Commission v. Ralston Purina Co., 346 U.S. 119,124 (1953); Campbell v. Degenther, 97 F. Supp. 975, 977 (W.D. Pa. 195 I). 